\title{
INTERMITTENT TEMPERATURES IN THE CONSERVATION OF 'BRS KAMPAI’ PEACHES
}

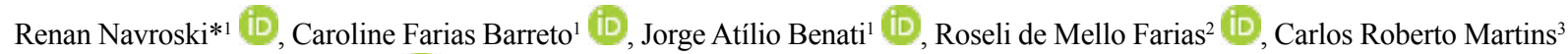 \\ \& Marcelo Barbosa Malgarim ${ }^{1}$
}

1 - Federal University of Pelotas, Faculty of Agronomy, Post-graduation Program of Agronomy, Pelotas, Rio Grande do Sul, Brazil

2 - State University of Rio Grande do Sul, São Borja, Rio Grande do Sul, Brazil

3 - Brazilian Agricultural Research Corporation, Embrapa Temperate Agriculture, Pelotas, Rio Grande do Sul, Brazil

\section{Keywords:}

Warming

Cold storage

Prunus persica

\section{ABSTRACT}

This study aimed at evaluating the quality of peaches borne by the cultivar BRS Kampai when cooled at intermittent temperatures throughout storage. They were stored at $1{ }^{\circ} \mathrm{C}$ and relative humidity between $80 \%$ and $90 \%$ in a cold storage chamber. The following treatments were applied: $\mathrm{T} 1$ - fruit stored at $1 \pm 0.5^{\circ} \mathrm{C} ; \mathrm{T} 2$ - fruit stored at $1 \pm 0.5^{\circ} \mathrm{C}$ and increase in temperature every five days to $25^{\circ} \mathrm{C}$; and $\mathrm{T} 3$ - fruit stored at $1 \pm 0.5^{\circ} \mathrm{C}$ and increase in temperature every seven days to $25^{\circ} \mathrm{C}$. Fruit were submitted to increase in temperature when they were withdrawn from the cold storage chamber and kept in a heated room. Evaluations were conducted when fruit were harvested, after 10 cold storage days and 2 days of commercialization simulation at $25^{\circ} \mathrm{C}$ $(10+2)$ and after 20 cold storage days and 2 days of commercialization simulation at $25^{\circ} \mathrm{C}(20+2)$. Peaches were evaluated in terms of mass loss, pulp firmness, soluble solids, titratable acidity, $\mathrm{pH}$ and epidermis color. T1 exhibited higher mass loss, higher soluble solid content and higher pulp firmness after 20 cold storage days, by comparison with the other treatments. T2 led to lower mass loss after 20 cold storage days than the ones of the other treatments. However, T2 also showed higher loss of pulp firmness in the same period. The use of intermittent temperatures throughout storage of 'BRS Kampai' peaches may be an alternative to extend their post-harvest period.

Palavras-chave:

Aquecimento

Armazenamento refrigerado

Prunus persica
TEMPERATURAS INTERMITENTES NA CONSERVAÇÃO DE PÊSSEGOS 'BRS KAMPAI'

\section{RESUMO}

O objetivo desta pesquisa foi avaliar a qualidade de frutos de pêssego da cultivar BRS Kampai, refrigerados com temperaturas intermitentes durante o armazenamento. Os frutos foram armazenados a temperatura de $1^{\circ} \mathrm{C}$, com umidade relativa de $80-90 \%$ em câmara fria. Os tratamentos utilizados foram $\mathrm{T} 1$ : frutos armazenados a temperatura de $1 \pm 0,5^{\circ} \mathrm{C}, \mathrm{T} 2$ : frutos armazenados a temperatura de $1 \pm 0,5^{\circ} \mathrm{C}$, com elevação da temperatura a cada cinco dias a temperatura de $25^{\circ} \mathrm{C}$, e T3: frutos armazenados a temperatura de $1 \pm 0,5^{\circ} \mathrm{C}$, com elevação da temperatura a cada sete dias a temperatura de $25^{\circ} \mathrm{C}$. A elevação da temperatura foi realizada retirando-se os frutos da câmara fria e mantendo-os em sala climatizada. As avaliações foram realizadas no momento da colheita, aos 10 de armazenamento refrigerado mais 2 dias de simulação de comercialização a $25^{\circ} \mathrm{C}(10+2)$ e aos 20 dias de armazenamento refrigerado mais 2 dias de simulação de comercialização a $25^{\circ} \mathrm{C}(20+2)$. Os pêssegos foram avaliados quanto a perda de massa, firmeza da polpa, sólidos solúveis, acidez titulável, pH e coloração da epiderme. Observou-se maior perda de massa e teor de sólidos solúveis no T1, assim como, maior firmeza de polpa aos 20 dias. O T2 proporcionou menor perda de massa em comparação com os demais tratamentos aos 20 dias. Porém, houve maior perda de firmeza da polpa neste tratamento no mesmo período. O uso de temperaturas intermitentes no armazenamento de pêssegos BRS Kampai pode ser uma alternativa para prolongar o seu período pós-colheita. 


\section{INTRODUCTION}

Peaches were the 12th most popular fruit worldwide in 2018 (FAOSTAT, 2018) and the 15th most popular one in Brazil in 2018 (ANUÁRIO BRASILEIRO DE HORTI E FRUTI, 2020). Their quality is usually determined by their appearance, color, texture, aroma, flavor, nutrition and food safety (RODRIGUES et al., 2020). Peaches have been valued due to their excellent aroma and flavor (ZHAO et al., 2019; ZHOU et al., 2019). Besides, they have been known to contribute to prevent several degenerative diseases (SUN et al., 2019) because of their high nutritional values and levels of anticarcinogenic antioxidants, such as carotenoids and phenolics (DURST; WEAVER, 2012).

In Brazil, characteristics of peach production depend on the growing regions. For instance, in Rio Grande do Sul (RS) state, most varieties aim at industrial processes and some have dual use (fresh and preserved fruit) while, in the other states, table peaches represent the main crop (FACHINELLO et al., 2011). RS has $74.6 \%$ of the Brazilian area where peach trees are grown and $66.7 \%$ of the national production (IBGE, 2018).

Peaches are seasonal fruit, i. e., just like most fruit, they are only harvested in a certain period of the year. Thus, in the off-season, their offer depends on importation.

In addition, two problems have affected this crop. Firstly, the market cannot absorb the whole quantity of harvested peaches; as a result, other solutions are needed to keep them in the market longer (PINTO et al., 2012). Secondly, the Brazilian current production does not meet the demand (MADAIL; RASEIRA, 2008). Thus, both longer storage periods - to broaden their availability in the market - and the need for long-distance transportation require techniques that may extend their shelf life after harvest. However, the main concern in the post-harvest phase is to keep the quality of the product so that it meets consumers' expectations and expands the market (FABIANE et al., 2019).

Cold storage is the most common method used worldwide to extend shelf life of fruit and vegetables while keeping their quality characteristics (RODRIGUES et al., 2020). However, many fruit species are sensitive to low temperatures and every cultivar has its critical limit (VITTI et al., 2007). Several authors agree that a large part of the cold storage process affects the quality of peaches, mainly when they are stored at low temperatures (ABBASI et al., 2019; LIU et al., 2019; ZHAO et al., 2019; ZHOU et al., 2019).

Storage techniques that use either intermittent temperatures or intermittent warming have recently enabled ideal maturation to be reached by controlling temperature and specific storage periods (LURIE; CRISOSTO, 2005). Efficacy consists in storing fruit after harvest at $0^{\circ} \mathrm{C}$ and, after a certain period, submit fruit to higher temperatures (from $20^{\circ} \mathrm{C}$ to $24^{\circ} \mathrm{C}$ ) for a day (RODRIGUES et al., 2020). Temporary increase in storage temperature enables fruit cells to metabolize either toxic or intermediate compounds that accumulated during exposure to low temperatures, repair membranes and organelles and regulate metabolic pathways (WANG, 1994).

In the attempt to decrease effects of physiological injuries, the use of intermittent temperatures around $25^{\circ} \mathrm{C}$ may be an efficient preservation method. Therefore, this study aimed at evaluating the quality of peaches borne by the cultivar BRS Kampai when cooled at intermittent temperatures throughout storage.

\section{MATERIAL AND METHODS}

Peaches borne by the cultivar BRS Kampai were harvested in an orchard implanted in 2013 at the Estação Experimental Agronômica that belongs to the Universidade Federal do Rio Grande do Sul (UFRGS), in Porto Alegre, RS, Brazil. They were randomly picked in four quadrants of canopies in November 2017. Afterwards, they were taken to the Laboratório de Qualidade das Frutas that belongs to the Universidade Federal de Pelotas (UFPel), in Pelotas, RS, Brazil.

A 10-fruit sample, with standardized fruit in terms of their maturation stage, was stored at $1{ }^{\circ} \mathrm{C}$ and $80-90 \%$ relative humidity in a cold storage chamber. The following treatments were used:

- $\mathrm{T} 1$ : fruit stored at $1 \pm 0.5^{\circ} \mathrm{C}$;

- T2: fruit stored at $1 \pm 0.5^{\circ} \mathrm{C}$ and natural increase 
in temperature to $25^{\circ} \mathrm{C}$ for 24 hours every five days;

- T3: fruit stored at $1 \pm 0.5^{\circ} \mathrm{C}$ and natural increase in temperature to $25^{\circ} \mathrm{C}$ for 24 hours every seven days.

Regarding natural increase in temperature, fruit were withdrawn from the cold storage chamber and kept in a heated room at previously described temperatures and periods. Evaluations were conducted when fruit were harvested, after 10 cold storage days and 2 days of commercialization simulation at $25^{\circ} \mathrm{C}(10+2)$ and after 20 cold storage days and 2 days of commercialization simulation at $25^{\circ} \mathrm{C}(20+2)$.

Peaches had the following attributes evaluated:

Mass loss, determined by the difference between fruit mass when they were harvested and when they were evaluated before storage and results expressed as percentage;

Pulp firmness, measured by a manual penetrometer (TR TURONI, Italy, model 53205), equipped with an 8-mm tip, at two opposite points in the equatorial regions of fruit and results expressed as Newton;

Epidermis color, carried out by a Minolta CR$300^{\circledR}$ colorimeter equipped with a D65 light source to read "L" (luminosity), "a*", "b*" and the shade or chromatic color represented by the Hue angle. Two readings were conducted in the equatorial regions of every fruit;

Soluble solids (SS), determined by an Atago ${ }^{\circledR}$ digital refractometer and results expressed as ${ }^{\circ} \mathrm{Brix}$;

Titratable acidity (TA), quantified in $10 \mathrm{~mL}$ juice diluted in $90 \mathrm{~mL}$ distilled water and titrated in an $\mathrm{NaOH} 0.1 \mathrm{~mol} / \mathrm{L}$ solution up to $\mathrm{pH} 8.1$ by a Quimus ${ }^{\circledR} \mathrm{pH}$ meter and results expressed as percentage of citric acid;

Power of hydrogen $(\mathrm{pH})$, measured by a Quimus ${ }^{\circledR} \mathrm{pH}$ meter.

The experiment had a thoroughly randomized design with a $3 \times 3$ factorial scheme ( 3 methods of intermittent temperature $\times 3$ storage periods) and four 10-fruit replicates. Data were submitted to the analysis of variance by the F-test and means were compared by the Tukey's test, where $\mathrm{p} \leq 0.05$.

\section{RESULTS AND DISCUSSION}

Table 1 shows results of mass loss, which did not differ in treatments up to 10 days of evaluation. It only differed after 20 days, when fruit stored at $1 \pm 0.5^{\circ} \mathrm{C}$ and increase in temperature to $25^{\circ} \mathrm{C}$ every five days (T2) were found to exhibit less than half of mass loss found in T1. Only T2 did not differ between 10 and 20 days, when the lowest mass loss was observed. According to Alves et al. (2009), mass loss of fresh matter in fruit is mainly caused by water loss through transpiration and respiration processes. This loss implies that the product loses quality.

Contents of soluble solids differed among treatments only after 20 cold storage days, when the ones found in $\mathrm{T} 1$ were higher than the others. It shows that these fruit were in a more advanced maturation stage. According to Jie et al. (2013), the more fruit ripen, the higher their sugar concentrations. It results from the fact that there is degradation of organic acids and their conversion to sugar. Moreno et al. (2008) have attributed increase in soluble solids in the storage periods to loss of mass that concentrates fruit juice, i. e., fruit lose water and solutes found in the pulp concentrate. This fact can be confirmed by the relation between the high mass loss in T1 after 20 cold storage days. T3 was the only treatment that did not exhibit any significant changes in values of soluble solids among storage periods.

Titratable acidity just exhibited significant difference among treatments after 20 cold storage days, considering the storage periods under study. T1 may have shown increase in titratable acidity due to high mass loss, which may have concentrated solutes in fruit pulp, i. e., water loss to the environment led to concentration of sugars and organic acids in the pulp.

Regarding ${ }^{\circ}$ Hue angles of fruit (Table 2), T1 differed among storage periods, since it exhibited the highest values of this attribute after 20 cold storage days. Considering all treatments, the difference was higher after 20 days; there was no difference between T2 and T3 in this period. High ${ }^{\circ}$ Hue values in peaches show greenish epidermis. 
Table 1. Means followed by the standard deviation of values of mass loss expressed as percentage, content of soluble solids as ${ }^{\circ} \mathrm{Brix}$ (SS) and titratable acidity as mg citric acid.100g of 'BRS Kampai' peach pulp stored for three periods (0,10 and 12 days) and submitted to intermittent regimes. FAEM/ UFPel, Pelotas, RS, Brazil, 2017

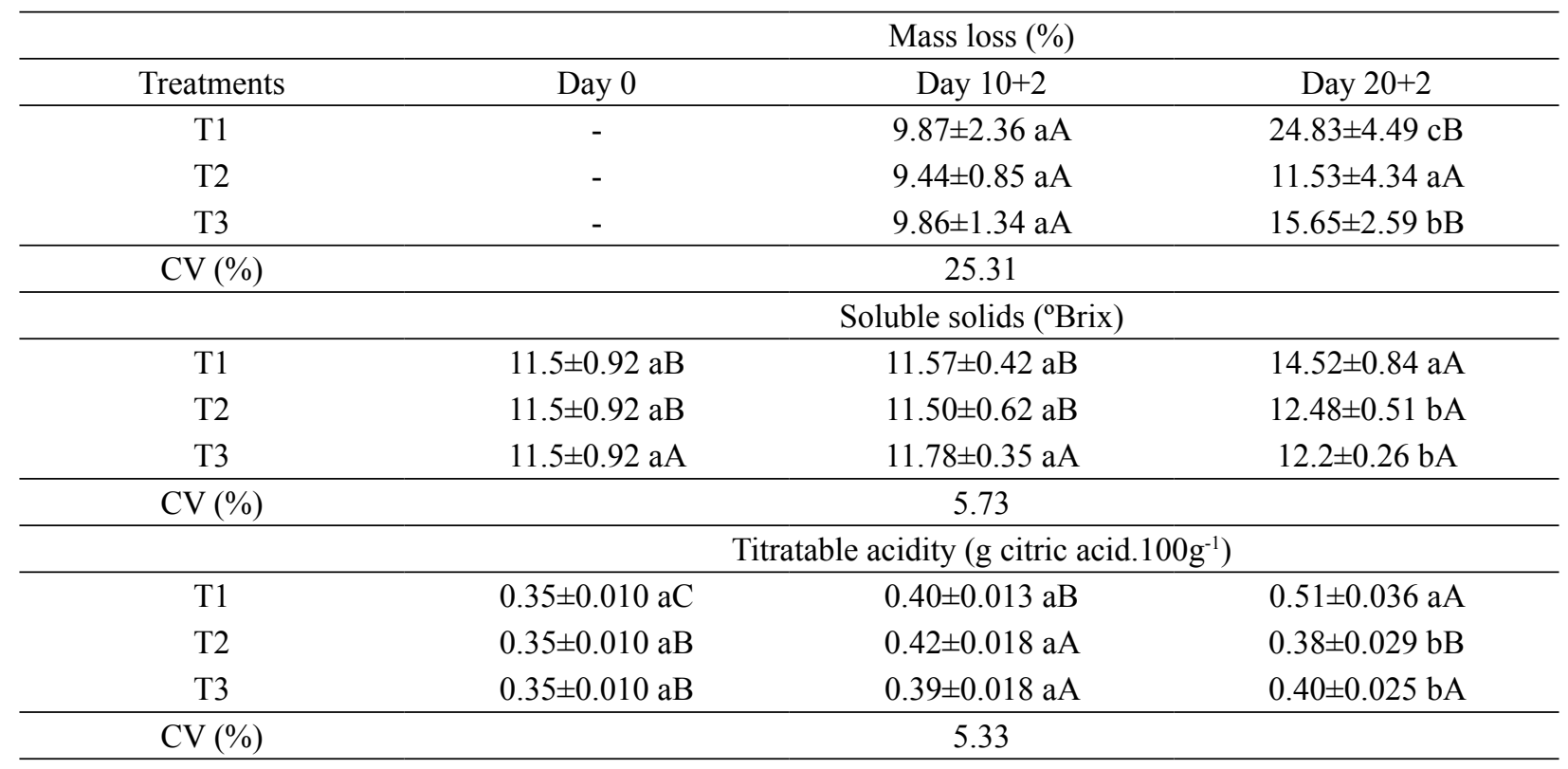

Means followed by certain lowercase letters in a column and uppercase ones in a line do not differ by the Tukey's test at 5\% significance. CV: coefficient of variation

The lower the values, the redder the fruit. Thus, fruit color exhibited the highest ${ }^{\circ}$ Hue values on the harvest day (Table 2), when epidermis was greenish cream. Decrease in ${ }^{\circ}$ Hue values throughout the storage periods shows that fruit epidermis became reddish cream, which means advance in maturation. This change was not found in $\mathrm{T} 1$, since it did not differ from 20 storage days to the harvest day. Similar results of 'BRS Kampai' peaches were described by Barreto et al. (2019).

Pulp firmness only decreased in T2. Differences were found among all storage periods. There was no statistical difference in $\mathrm{T} 1$ and $\mathrm{T} 2$ between 10 and 20 days. Decrease in pulp firmness is due to the solubilization of pectin chains and consequent breakdown of middle lamellae and rupture of cell walls (BILLY et al., 2008; ZHANG et al., 2010). Loss in pulp firmness of peaches after storage was also reported by Barreto et al. (2017) and Barreto et al. (2019).

Table 3 shows means of attributes that did not exhibit any significant interaction between treatments and storage periods. The juice $\mathrm{pH}$ exhibited significant differences neither among treatments nor among storage periods. According to Alcobendas et al. (2013), $\mathrm{pH}$ is a characteristic that is connected to environmental factors and location of fruit in plants. Barreto et al. (2019) has not found any change in peach juice $\mathrm{pH}$ as the result of storage periods, either.

Epidermis chromaticity increased in the storage periods. It represents color saturation, i. e., higher values of chroma represent brighter colors (saturated ones) while lower values represent less bright colors. Thus, epidermis color became more saturated throughout the storage period, an effect that results from advance in fruit maturation. Increase in chromaticity and decrease in ${ }^{\circ} \mathrm{Hue}$ show intensification of red as the result of fruit ripening, which makes them more attractive (BORGES et al., 2013). This change is due to chlorophyll breakdown and simultaneous synthesis of other pigments, such as carotenoids and anthocyanins (CHITARRA; CHITARRA, 2005), making the epidermis get redder.

The relation between soluble solids and titratable acidity (SS/TA) is the indicator used for determining the maturation stage and the balance between sweet:sour taste (COUTO et al., 2010). Table 3 shows decrease in this relation after 10 
Table 2. Means followed by standard deviation of Hue angle and pulp firmness values (N) of 'BRS Kampai' peaches stored for three periods (0,10 and 20 days) and submitted to intermittent regimes. FAEM/ UFPel, Pelotas, RS, Brazil, 2017

\begin{tabular}{cccc}
\hline \multicolumn{4}{c}{${ }^{\circ} \mathrm{Hue}$} \\
\hline Treatments & Day 0 & Day 10+2 & Day 20+2 \\
\hline T1 & $77.76 \pm 3.72 \mathrm{aA}$ & $64.33 \pm 1.62 \mathrm{bB}$ & $76.78 \pm 3.48 \mathrm{aA}$ \\
$\mathrm{T} 2$ & $77.76 \pm 3.72 \mathrm{aA}$ & $72.77 \pm 2.90 \mathrm{aAB}$ & $68.15 \pm 6.12 \mathrm{bB}$ \\
$\mathrm{T} 3$ & $77.76 \pm 3.72 \mathrm{aA}$ & $58.56 \pm 4.92 \mathrm{abB}$ & $66.69 \pm 4.02 \mathrm{bB}$ \\
\hline $\mathrm{CV}(\%)$ & 5.51 \\
\hline \multicolumn{4}{c}{ Pulp firmness } \\
\hline T1 & $26.73 \pm 0.66 \mathrm{aA}$ & $14.02 \pm 1.67 \mathrm{bB}$ & $17.38 \pm 2.20 \mathrm{aB}$ \\
$\mathrm{T} 2$ & $26.73 \pm 0.66 \mathrm{aA}$ & $18.43 \pm 2.26 \mathrm{aB}$ & $13.48 \pm 2.25 \mathrm{bC}$ \\
\hline T3 & $26.73 \pm 0.66 \mathrm{aA}$ & $17.32 \pm 2.62 \mathrm{abB}$ & $14.37 \pm 2.83 \mathrm{abB}$ \\
\hline
\end{tabular}

Means followed by certain lowercase letters in a column and uppercase ones in a line do not differ by the Tukey's test at $5 \%$ significance. $\mathrm{CV}$ : coefficient of variation

Table 3. Means followed by standard deviation of values of $\mathrm{pH}$, chromaticity and relation between soluble solids and titratable acidity of 'BRS Kampai' peaches stored for three periods ( 0,10 and 20 days) and submitted to intermittent regimes. FAEM/UFPel, Pelotas, RS, Brazil, 2017

\begin{tabular}{cccc}
\hline Treatments & $\mathrm{pH}$ & Chroma & SS/TA \\
\hline T1 & $4.49 \pm 0.08^{\mathrm{ns}}$ & $30.11 \pm 1.41^{\mathrm{ns}}$ & $30.32 \pm 2.96^{\mathrm{ns}}$ \\
$\mathrm{T} 2$ & $4.03 \pm 0.06$ & $30.44 \pm 1.56$ & $30.71 \pm 4.17$ \\
$\mathrm{~T} 3$ & $4.02 \pm 0.05$ & $30.34 \pm 1.50$ & $31.09 \pm 2.69$ \\
\hline Periods & & & $32.87 \pm 3.07 \mathrm{a}$ \\
\hline Day 0 & $4.06 \pm 0.047^{\mathrm{ns}}$ & $28.71 \pm 1.36 \mathrm{~b}$ & $28.53 \pm 2.14 \mathrm{~b}$ \\
Day 10+2 & $4.0 \pm 0.058$ & $30.93 \pm 0.70 \mathrm{a}$ & $30.74 \pm 3.08 \mathrm{ab}$ \\
\hline Day 20+2 & $4.49 \pm 0.072$ & $31.25 \pm 0.48 \mathrm{a}$ & 8.74 \\
\hline CV $(\%)$ & 24.23 & 3.26 & \\
\hline
\end{tabular}

Means followed by certain lowercase letters in a column and uppercase ones in a line do not differ by the Tukey's test at $5 \%$ significance. CV: coefficient of variation

days of cold storage, followed by some stability. After 20 days, there was no statistical difference between that period and the other storage periods. It may have occurred as the result of interaction among other attributes, such as titratable acidity itself, whose behavior was similar, besides mass loss, which may change concentrations of solutes in fruit pulp.

\section{CONCLUSIONS}

- Results of attributes under evaluation varied. T2 exhibited promising results of mass loss, although it showed the highest firmness loss. Thus, a specific storage protocol cannot be recommended.
- The use of intermittent temperatures throughout storage of 'BRS Kampai' peaches may be an alternative solution to extend their post-harvest period. However, further studies of different temperatures and their combination, besides the evaluation of other cultivars, are needed.

\section{AUTHORSHIP CONTRIBUTION STATEMENT}

NAVROSKI, R.: Data curation, Formal Analysis, Investigation, Software, Writing-original draft; BARRETO, C.F.: Conceptualization, Data curation, Formal Analysis, Investigation, Methodology; BENATI, J.A.: Data curation, Formal Analysis, Investigation; FARIAS, R.M.: Investigation, Methodology, Supervision, Writing 
- review \& editing; MARTINS, C.R.: Project administration, Resources, Supervision, Writing - review \& editing; MALGARIM, M.B.: Project administration, Resources, Supervision, Writing review \& editing.

\section{DECLARATION OF INTERESTS}

The authors declare that they have no known competing financial interests or personal relationships that could have appeared to influence the work reported in this paper.

\section{REFERÊNCIAS}

ABBASI, N. A.; ALI, I.; HAFIZ, I. A.; ALENAZI, M. M.; SHAFIQ, M. Effects of putrescine application on peach fruit during storage. Sustainability, v. 11, n. 7, p. 1-17, 2019.

ALCOBENDAS, R.; MIRÁS-AVALOS, J. M.; ALARCÓN, J. J.; NICOLÁS, E. Effects of irrigation and fruit position on size, colour, firmness and sugar contents of fruits in a mid-late maturing peach cultivar. Scientia Horticulturae, v. 164, p. 340-347, 2013.

ALVES,E.D.O.; STEFFENS, C.A.;AMARANTE, C. V. T. D.; WEBER, A.; MIQUELOTO, A.; BRACKMANN, A. Armazenamento refrigerado de ameixas 'Laetitia' com uso de 1-MCP e indução de perda de massa fresca. Ciência Rural, v. 40, n. 1, p. 30-36, 2009.

ANUÁRIO BRASILEIRO DE HORTI E FRUTI 2020. CEPEA, Piracicaba, São Paulo: Available: http://www.editoragazeta.com.br/produto/anuariobrasileiro-de-horti-fruti-2020/ . Accessed Nov. 18, 2020.

BARRETO, C. F.; FERREIRA, L. V.; NAVROSKI, R.; FRASSON, S. F.; CANTILLANO, R. F. F.; VIZZOTTO, M.; ANTUNES, L. E. C. Adubação nitrogenada em pessegueiros (Prunus persica (L.) batsch): influência sobre a qualidade póscolheita. Revista Iberoamericana de Tecnología Postcosecha, v. 18, n. 2, p. 93-99, 2017.
BARRETO, C. F.; NAVROSKI, R.; BENATI, J. A.; FARIAS, R. M.; MARTINS, C. R.; MALGARIM, M. B. Conservação e qualidade de pêssegos 'BRS Kampai' na pós-colheita. Revista Científica Rural, v. 21, n. 1, p. 131-141, 2019.

BILLY, L.; MEHINAGIC, E.; ROYER, G.; RENARD, C. M.; ARVISENET, G.; PROST, C.; JOURJON, F. Relationship between texture and pectin composition of two apple cultivars during storage. Postharvest Biology and Technology, v. 47, n. 3, p. 315-324, 2008.

BORGES, C. D.; MENDONÇA, C. R. B.; ZAMBIAZI, R. C.; DA SILVA, E. M. P.; PAIVA, F. F. Conservação de morangos com revestimentos à base de goma xantana e óleo essencial de sálvia. Bioscience Journal, v. 29, n. 5, p. 1071-1083, 2013.

ChITARrA, M. I. F.; ChitARRA, A. B. Póscolheita de frutos $\mathrm{e}$ hortaliças: fisiologia $\mathrm{e}$ manuseio. 2. ed. rev. e ampl. Lavras: UFLA, 2005.

COUTO, M. A. L.; CANNIATTI-BRAZACA, S. G. Quantificação de vitamina $C$ e capacidade antioxidante de variedades cítricas. Ciência e Tecnologia de Alimentos, v. 30, n. 1, p. 15-19, 2010.

DURST, R.W.; WEAVER, G.W. Nutritional content of fresh and canned peaches. Journal of the Science of Food and Agriculture, v. 93, n. 3, p. 593-603, 2012.

FACHINELLO, J. C.; PASA, M. D. S.; SCHMTIZ, J. D.; BETEMPS, D. L. Situação e perspectivas da fruticultura de clima temperado no Brasil. Revista Brasileira de Fruticultura, v. 33, p. 109-120, 2011.

FABIANE, K. C.; JÚNIOR, A. W.; DOTTO, M.; VAL, J.; SANCHEZ, M. A. M. Qualidade e suscetibilidade de pêssegos e nectarinas aos danos causados pelo frio. Colloquium Agrariae, v. 15, n. 3, p. 22-39, 2019.

FAOSTAT, FAO. Statistical databases. Food and Agriculture Organization of the United Nations, 2018. Available: http://www.fao.org/faostat/en/. Accessed Nov. 18, 2020. 
INSTITUTO BRASILEIRO DE GEOGRAFIA E ESTATÍSTICA - IBGE. Produção agrícola municipal. Rio de Janeiro: IBGE, 2018. Available: http://www.sidra.ibge.gov.br/bda/tabela/protabl. asp? $=1613 \& z=\& 0=24 \& \mathrm{i}=$ P. Accessed Mar. 9, 2020.

JIE, D.; XIE, L.; FU, X.; RAO, X.; YING, Y. Variable selection for partial least squares analysis of soluble solids content in watermelon using nearinfrared diffuse transmission technique. Journal of Food Engineering, v. 118, p. 387-392, 2013.

LIU, H.; JIANG, W.; CAO, J.; LI, Y. Effect of chilling temperatures on physiological properties, phenolic metabolism and antioxidant level accompanying pulp browning of peach during cold storage. Scientia Horticulturae, v. 255, p. 175-182, 2019.

LURIE, S.; CRISOSTO, C. H. Chilling injury in peach and nectarine. Postharvest Biology and Technology, v. 37, n. 3, p. 195-208, 2005.

MADAIL, J. C. M.; RASEIRA, M. C. B. Aspectos da produção e mercado do pêssego no Brasil. Pelotas-RS: Embrapa Clima Temperado, 2008. (Circular Técnica, n.80). Available: <http://www.cpact.embrapa.br/ publicacoes $>$. Accessed Agu. 20, 2020.

MODESTO, J. H.; VEDOATO, B. T. F.; LEONEL, S.; TECCHIO, M. A. Crescimento vegetativo, fenologia, produção e sazonalidade dos frutos de pessegueiros e nectarineiras. Revista Magistra, v. 26, n. 4, p.425-430, 2014.

MORENO, J. J.; CERPA-CALDERÓN, F.; COHEN, S. D.; FANG, Y.; QIAN, M.; KENNEDY, J. A. Effect of postharvest dehydration on the composition of Pinot Noir grapes (Vitis vinifera L.) and wine. Food Chemistry, v. 109, p. 755-762, 2008.

PINTO, J. A. V.; BRACKMANN, A.; SCHORR, M. R. W.; VENTURINI, T. L.; THEWES, F. R. Indução de perda de massa na qualidade pós-colheita de pêssegos 'Eragil' em armazenamento refrigerado. Ciência Rural, v. 42, n. 6, p. 962-968, 2012.
RODRIGUES, C.; GASPAR, P. D.; SIMÕES, M. P.; SILVA, P. D.; ANDRADE, L. P. Review on techniques and treatments toward the mitigation of the chilling injury of peaches. Journal of Food Processing and Preservation, p. e14358, 2020.

SUN, H.; ANGELIDAKI, I.; WU, S.; DONG, R.; ZHANG, Y. The potential of bioelectrochemical sensor for monitoring of acetate during anaerobic digestion: Focusing on novel reactor design. Frontiers in microbiology, v. 9, p. 3357, 2019.

VITTI, D. C. C.; KLUGE, R. A.; JACOMINO, A. P.; LIMA, G. P. P. Tratamento térmico para controle da lanosidade em pêssegos 'Dourado-2' refrigerados. Pesquisa Agropecuária Brasileira, v. 42, n. 12, p. 1705-1713, 2007.

WANG, C.Y. Chilling injury of tropical horticultural commodities. HortScience, v. 29, n. 9, p. 986-988, 1994.

ZHANG, L.; CHEN, F.; YANG, H.; SUN, X.; LIU, H.; GONG, X.; JIANG, C; DING, C. Changes in firmness, pectin content and nanostructure of two crisp peach cultivars after storage. Food Science and Technology, v. 43, n. 1, p.26-32, 2010.

ZHAO, H.; JIAO, W.; CUI, K.; FAN, X.; SHU, C.; ZHANG, W.; CAO, J.; JIANG, W. Near-freezing temperature storage enhances chilling tolerance in nectarine fruit through its regulation of soluble sugars and energy metabolism. Food Chemistry, v. 289 , p. $426-435,2019$.

ZHOU, D.; SUN, Y.; LI, M.; ZHU, T.; TU, K. Postharvest hot air and UV-C treatments enhance aroma-related volatiles by simulating the lipoxygenase pathway in peaches during cold storage. Food Chemistry, v. 292, p. 294-303, 2019. 